\title{
Chemical Compostion of Earthen Pond Feed from Spring Water, in Asaba Campus, Asaba, Delta State,
} Nigeria

\author{
Olele Nkeonyeasua Florence, Nwabueze Arimiche Agatha and Ekelemu Jerimoth Kesiana \\ Department of Fisheries, Delta State University, Asaba Campus, PMB 95074, Delta State, Nigeria
}

Received: September 17, 2012 / Published: January 20, 2013.

\begin{abstract}
Sound pond productivity accompanied with adequate fish health is maintained, when water quality parameters are conducive. The study evaluated the chemical composition of a pond feed from spring water, in Asaba Campus. Sampling was carried out from September 2011 to February 2012 on a monthly basis. Surface water samples were collected between the hours of 7:00-9:00 am from the pond on each sampling day. Hydrogen-ion-concentration was in the range of 6.5 to 8.0 units. Dissolved oxygen was the highest in February 2012 with a value of $11.0 \mathrm{mg} / \mathrm{L}$ while it was the lowest in December 2011 with a value of 9.0 mg/L. Biological oxygen demand ranged from 3.5 to $5.0 \mathrm{mg} / \mathrm{L}$. The chemical oxygen demand was the highest in December $(10.00 \mathrm{mg} / \mathrm{L}) \mathrm{and}$ lowest between January and February $(8.0 \mathrm{mg} / \mathrm{L})$. The highest alkalinity was observed in October with a value of $1.05 \mathrm{mg} / \mathrm{L}$ and lowest in December with a value of $0.042 \mathrm{mg} / \mathrm{L}$. Conductivity values ranged from 0.075 to $0.12 \mu \mathrm{S} / \mathrm{cm}$. Total phosphorus was the highest in October with a value of $1.01 \mathrm{mg} / \mathrm{L}$ and lowest in December with a value of $0.83 \mathrm{mg} / \mathrm{L}$. Total dissolved solids ranged from 90 to 105 $\mathrm{mg} / \mathrm{L}$. Values of physco-chemical parameters revealed that the pond was not polluted. Water quality analysis of the aquatics is of economic advantage to the fish farmer, hence, the need for its assessment at regular intervals. This is a quality assurance process that assures early dictation of toxic substances and mitigation processes to adopt before problems arise. In this way, the good health of organisms in the aquatic ecosystem and those of human dependent on them are guaranteed.
\end{abstract}

Key words: Chemical composition, pond water, spring water, Asaba campus, Asaba, Delta State, Nigeria.

\section{Introduction}

Water bodies are potential media for the production of aquatic organism [1]. This is because such media are conducive for the functioning and sustenance of aquatic lifes [2]. Access to regular and adequate, supply and maintenance of good water quality will guarantee the wellbeing of aquatic organisms for a successful aquaculture venture.

Fishes like other organisms have tolerable limits for water quality parameters in which they perform optimally. Any abnormal drop or increase within these limits adversely affects their body functions [3]. The recent increases in intensive aquaculture production in

Corresponding author: Olele Nkeonyeasua Florence, Ph.D., associate professor, research fields: fish breeding and hydrobiology. E-mail: nkeonyeasua.olele@uniben.edu.
Nigeria require adequate knowledge of water quality in order to apply necessary management measures as the need arises [4].

Water quality is the combination of properties of water that are manifested in relation to their usage for human activities and usage by other living creatures etc. [5]. Water is the most abundant compound on the Earth's surface, covering about $70 \%$ of the planet [6]. Springs are the surface evidence of a vast underground water resource [7]. According to both authors, most springs have conductivity ranges between 120 and $4,300 \mu \mathrm{S} / \mathrm{cm}$. However, the specific conductance of spring water recommemded was generally less than or equal to $500 \mu \mathrm{S} / \mathrm{cm}$. They opined that such conductance indicates the presence of small amounts of minerals dissolved in them [8]. The quality and 
quantity of water discharged by springs varies greatly because of factors such as the quality of water recharging the aquifer and the nature of bedrock/substratum over which the spring water flows through [9]. Water quality could be impaired when freshwater mixes with pockets of ancient seawater in the aquifer or when seawater along the coast mixes with spring water, thus representing the general water quality in the ground-water system [9].

Chemical composition of spring water are oxygen demand $(8.5 \mathrm{mg} / \mathrm{L})$, biological oxygen demand (4.5 $\mathrm{mg} / \mathrm{L})$, total dissolved solids $(102 \mathrm{mg} / \mathrm{L}), \mathrm{pH}(7.2$ units) and dissolved oxygen $(10 \mathrm{mg} / \mathrm{L})$ concentrations [10]. The Albert Agriculture and Rural Development reported standard composition for spring water as follows: hardness $(48.00 \mathrm{mg} / \mathrm{L})$, conductivity $(0.05$ $\mathrm{mS} / \mathrm{cm})$, total phosphorus $(0.79 \mathrm{mg} / \mathrm{L})$, fluoride $(0.50$ $\mathrm{mg} / \mathrm{L})$, nitrite $(1.00 \mathrm{mg} / \mathrm{L})$, nitrate $(1.4 \mathrm{mg} / \mathrm{L})$, chloride $(19.7 \mathrm{mg} / \mathrm{L})$, sodium $(18.1 \mathrm{mg} / \mathrm{L})$, potassium $(8.77$ $\mathrm{mg} / \mathrm{L})$ and ammonia $(0.97 \mathrm{mg} / \mathrm{L})$ [11]. It was reported that the overall $\mathrm{pH}$ range for spring water was generally between 6 and 8 units [12]. From the fore reports, it is evident that no study has been conducted on the chemical composition of the pond of study. The environment of the pond is a dumping ground for domestic wastes disposal from-inhabitants in that locality. Knowledge of the water quality status and probable extent of pollution in the pond becomes essential in order to preserve its valuable resources for future generation.

\section{Materials and Methods}

\subsection{Study Area}

The study area is located between longitude $06^{\circ} 49^{\prime} \mathrm{E}$ and latitude $06^{\circ} 14^{\prime} \mathrm{N}$ of the equator. The pond lies in the tropical rainforest zone, characterized by seven months of rainy season that spans between April and October, punctuated by a short break in August when there was very little or no rainfall. The annual rainfall of the study area ranged between $1,500.0$ and $1,849.3 \mathrm{~mm}[13]$.

\subsection{Sample Collection}

Sampling was conducted between September, 2011 and February, 2012 from the ponds on a monthly basis, between the hours of 7:00 and 9:00 am on each sampling day. The samples were immediately conveyed in an ice chest to the Fisheries Laboratory (located within the campus) for chemical analysis as reported [14].

Mean monthly concentrations for $\mathrm{pH}$, dissolved oxygen, biological oxygen demand, chemical oxygen demand, alkalinity, conductivity and total phosphorus were analyzed using standard procedures [15].

\subsection{Statistical Analysis}

Data generated from the laboratory, were subjected to one way analysis of variance (ANOVA) using the SPSS software. Differences between means were separated using Duncan's Multiple Range Test (DMRT).

\section{Results and Discussion}

Water quality studies are essential for setting base line standards [14]. This is because against these standards further studies can be evaluated.

\subsection{Chemical Oxygen Demand (COD)}

Data on chemical oxygen demand (COD) of the pond are presented in Table 1. Significant differences $(P<0.05)$ were observed during the months. The table further shows that the highest value for COD was recorded in December 2011 with a value of 10.00 $\mathrm{mg} / \mathrm{L}$ and lowest between January and February 2012 with a value of $8.0 \mathrm{mg} / \mathrm{L}$. These values were higher than those reported in dug well pond having a range of $2.15 \pm 0.16 \mathrm{mg} / \mathrm{L}$ to $2.64 \pm 0.14 \mathrm{mg} / \mathrm{L}$; and for borehole tank with a range of $1.27 \pm 0.06 \mathrm{mg} / \mathrm{L}$ to $2.21 \pm 0.52 \mathrm{mg} / \mathrm{L}$ [16]. However, higher values were recorded in earthen ponds $30.87 \mathrm{mg} / \mathrm{L}$ to $134.65 \mathrm{mg} / \mathrm{L}$ by the same researchers. The higher value of 162-397 $\mathrm{mg} / \mathrm{L}$ reported [14] corroborates with the results of other researchers [17], but were in contrast with those 
of present study.

Chemical oxygen demand determines the concentration of oxygen required for chemical oxidation of organic matter. It also shows the amount of dissolved oxygen used for the oxidation of organic matter including the non-biodegradable matters present in the habitat. Low concentration indicates the presence of low organic matter, while high concentration indicates pollution resulting from high organic matter decomposition [16]. The concentration in this study shows that the pond was not polluted. This revelation is based on the fact that the pond contains low concentration of organic matter.

\subsection{Biochemical Oxygen Demand (BOD)}

Biochemical oxygen demand varied significantly during the study. The highest value was $5.5 \mathrm{mg} / \mathrm{L}$ while the least was $3.5 \mathrm{mg} / \mathrm{L}$ Table 1 . Both values are below the standard limits of $30 \mathrm{mg} / \mathrm{L}$, reported for polluted water [18]. This observation was suggestive that the pond water of study was not polluted and so the fishes may not be negatively affected. However, a lower permissible limit of $4 \mathrm{mg} / \mathrm{L}$ for polluted water was reported [19]. This later value was comparable with those of present study, where a value of $5.5 \mathrm{mg} / \mathrm{L}$ was observed. This revelation suggests that the pond of study was likely to be experiencing mild pollution. Data realized from the present study was slightly higher than those reported [14] where a range value of 1.69 to $3.38 \mathrm{mg} / \mathrm{L}$ was observed. The accumulation of low concentration of BOD in stressed organisms could be suffocating to organisms, leading to death [19].

\subsection{Dissolved Oxygen (DO)}

Table 1 shows variation in dissolved oxygen concentration in the pond of study. The values were highest in February 2012 (11.0 mg/L) and lowest in December 2011 (9.0 mg/L). No significant differences were noticed for the data realised in the months of November and January. The values [16] reported in dug well pond $(4.8 \pm 0.76 \mathrm{mg} / \mathrm{L}$ to $6.30 \pm 0.17 \mathrm{mg} / \mathrm{L})$ was lower and in contrast with those of the present study. Similarly, the dissolved oxygen concentration of borehole tank reported by same authors was equally low $4.22 \pm 0.18$ to $5.74 \pm 0.52 \mathrm{mg} / \mathrm{L}$. Other values reported in earthen ponds were even lower, ranging from 2.35 to $6.25 \mathrm{mg} / \mathrm{L}$ [16]. The high concentration of dissolved oxygen in the present study shows that the pond was not polluted. This observation emanates from the fact that the pond is supplied from nearby spring that flow's in from a height. This action entraps oxygen, which enriched its concentration in the pond. The pond may also have had the high capacity to hold oxygen. Data on dissolved oxygen (9.0-11.0 mg/L) obtained from this study was lower than those reported [20], 9.3-16.2 $\mathrm{mg} / \mathrm{L}$. They opined that the minimum value of oxygen required in any tropical fish culture was $5 \mathrm{mg} / \mathrm{L}$. Dissolved oxygen in its aqueous state plays a vital role in the biology of cultured organisms [21].

\subsection{Total Dissolved Solid (TDS)}

The total dissolved solid observed in the present study varied from $90 \mathrm{mg} / \mathrm{L}$ in February to $105 \mathrm{mg} / \mathrm{L}$ in December, Table 1. This value was in contrast with those of researchers [14] who reported higher values (22-960 $\mathrm{mg} / \mathrm{L})$ where farmers used feeds to supplement pond nutrients. Opinion expressed by other researchers [22, 23] revealed that feeds introduced into ponds during fish rearing often increased the total dissolved solids which may pollute the system. The total dissolved solids of dug well pond [16] were comparable with those of present study. It ranged from $100.91 \pm 12.1 \mathrm{mg} / \mathrm{L}$ to $120.78 \pm$ $0.40 \mathrm{mg} / \mathrm{L}$. Similarly, the variation in total dissolved solids of borehole tank ranged from 88.21 \pm 0.72 $\mathrm{mg} / \mathrm{L}$ to $111.34 \pm 2.05 \mathrm{mg} / \mathrm{L}$ [16]. Higher values were also reported [16] for analysis made in earthen pond whose values ranged from 323 to $1,132 \mathrm{mg} / \mathrm{L}$.

In water bodies, total dissolved solids could be high especially when they are composed of carbonates, bicarbonates, chlorides, phosphates and nitrates of 
Table 1 Mean chemical composition of a pond feed by spring water.

\begin{tabular}{lllllllll}
\hline $\begin{array}{l}\text { Sampling } \\
\text { period }\end{array}$ & COD $(\mathrm{mg} / \mathrm{L})$ & $\begin{array}{l}\text { BOD } \\
(\mathrm{mg} / \mathrm{L})\end{array}$ & DO $(\mathrm{mg} / \mathrm{L})$ & TDS $(\mathrm{mg} / \mathrm{L})$ & $\mathrm{pH}$ units & $\begin{array}{l}\text { Total } \\
(\mathrm{mg} / \mathrm{L})\end{array}$ & $\begin{array}{c}\text { alkalinlty Conductivity } \\
(\mu \mathrm{S} / \mathrm{cm})\end{array}$ & $\mathrm{P}(\mathrm{mg} / \mathrm{L})$ \\
\hline Sept. & $9.00^{\mathrm{c}}$ & $5.00^{\mathrm{b}}$ & $9.50^{\mathrm{d}}$ & $100.00^{\mathrm{ab}}$ & $8.00^{\mathrm{a}}$ & $0.08^{\mathrm{b}}$ & $0.080^{\mathrm{ab}}$ & $0.85^{\mathrm{b}}$ \\
Oct. & $8.50^{\mathrm{d}}$ & $4.50^{\mathrm{c}}$ & $10.00^{\mathrm{c}}$ & $102.01^{\mathrm{ab}}$ & $7.50^{\mathrm{b}}$ & $1.00^{\mathrm{a}}$ & $0.100^{\mathrm{a}}$ & $1.01^{\mathrm{a}}$ \\
Nov. & $9.50^{\mathrm{b}}$ & $4.00^{\mathrm{d}}$ & $10.50^{\mathrm{b}}$ & $98.00^{\mathrm{b}}$ & $6.50^{\mathrm{cd}}$ & $1.05^{\mathrm{a}}$ & $0.075^{\mathrm{b}}$ & $0.90^{\mathrm{ab}}$ \\
Dec. & $10.00^{\mathrm{a}}$ & $3.50^{\mathrm{e}}$ & $9.00^{\mathrm{e}}$ & $90.00^{\mathrm{c}}$ & $7.00^{\mathrm{c}}$ & $0.042^{\mathrm{c}}$ & $0.090^{\mathrm{a}}$ & $0.83^{\mathrm{b}}$ \\
Jan. & $8.00^{\mathrm{e}}$ & $5.50^{\mathrm{a}}$ & $10.55^{\mathrm{b}}$ & $103.03^{\mathrm{ab}}$ & $6.80^{\mathrm{c}}$ & $0.070^{\mathrm{b}}$ & $0.120^{\mathrm{a}}$ & $0.95^{\mathrm{a}}$ \\
Feb. & $8.00^{\mathrm{e}}$ & $5.00^{\mathrm{b}}$ & $11.00^{\mathrm{a}}$ & $105.30^{\mathrm{a}}$ & $7.88^{\mathrm{a}}$ & $0.045^{\mathrm{c}}$ & $0.083^{\mathrm{ab}}$ & $0.79^{\mathrm{c}}$ \\
\hline
\end{tabular}

Values with the same superscript on the same column are not significantly different at $(P>0.05)$ confidence limits. Where COD $=$ chemical oxygen demand, $\mathrm{BOD}=$ biological oxygen demand, $\mathrm{DO}=$ dissolved oxygen, $\mathrm{TDS}=$ total dissolved solids, $\mathrm{pH}=\mathrm{hydrogen}$ ion concentration and $\mathrm{TP}=$ total phosphorus.

calcium, magnesium, sodium, potassium manganese, organic matter, salt and other particles [16]. High values reflect the extent of pollution, while low values reflect conductive water quality. The highest amount of TDS observed in the present study is low (105.30 $\mathrm{mg} / \mathrm{L}$ ) when compared to $500 \mathrm{mg} / \mathrm{L}$ reported by Standard Organization of Nigeria, 2007. The pond of study is therefore not polluted.

\subsection{Hydrogen-ion-concentration $(\mathrm{pH})$}

Values for $\mathrm{pH}$ in this study ranged from 6.5 to 8.0 units Table 1. Significant differences $(P<0.05)$ were observed throughout the months except in December and January when no significant difference was recorded (Table 1). Values of this parameter could be compared with a value of 8.2 to 9.45 reported [16]. High $\mathrm{pH}$ values were a reflection of the alkaline nature of the pond [16]. This happening is a direct reflection of high temperature that reduced the solubility of carbon-iv-oxide. High photosynthetic activities could equally result to increased $\mathrm{pH}$ value. Adequate pond productivity and fish health could be maintained, when water $\mathrm{pH}$ was conductive. Adequate and desirable $\mathrm{pH}$ for freshwater pond as observed in the present study was 6.5-8.0. Similar $\mathrm{pH}$ ranges reported by other researchers are as follows: 5.5-10.0 units were reported [24]; 7.3-8.3 units were reported [25] while a range of 6.75-7.10 units was reported [14]. The desirable range for pond $\mathrm{pH}$ was 6.5-9.5 while a range of 5.5-10.0 units could still be acceptable [24].

\subsection{Total Alkalinity}

Alkalinity was the highest in November with a value of $1.05 \mathrm{mg} / \mathrm{L}$ and lowest in December with a value of $0.042 \mathrm{mg} / \mathrm{L}$, showing that from alkalinity view point, the water quality of the pond of study was conducive. Data of the present study was lower than the value $10.6 \mathrm{mg} / \mathrm{L}$, reported [26] and 10.04-12.47 $\mathrm{mg} / \mathrm{L}$ [14]. Alkalinity is the buffering capacity of water. Waters with high alkalinity are undesirable because of the associated excessive hardness or high concentrations of sodium salts contained in them [14]. However, the reported alkalinity in the present study was within the acceptable range for aquaculture practices [27]. An alkalinity range of $25-100 \mathrm{mg} / \mathrm{L}$, recommended [28], was far higher than the ones reported earlier. Thus, the result of this study in terms of alkalinity was not supportive of those reported [28]. Alkalinity concentration was important for fish culture, because it was a measure of the calcium and magnesium status of the water body.

The alkaline nature of water bodies emanates from the presence of $\mathrm{OH}, \mathrm{CO}_{3}$ and $\mathrm{HCO}_{3}$ ions, together with the ability of the water to resist changes in $\mathrm{pH}$ upon addition of acid. The alkalinity of dug well pond was low [16]. The high alkalinity reported during certain months of the study may be due to low water table and lower temperature bringing down the rate of decomposition of salts to a minimum thereby increasing alkalinity [16].

The alkalinity range of 35 to $135 \mathrm{mg} / \mathrm{L}$ reported [14] 
was higher than that of the present study. A higher alkalinity range of $171.2-235.5 \mathrm{mg} / \mathrm{L}$ was reported for unpolluted pond [29]. The conflicting data on the standards for evaluating water bodies based on their alkalinity concentrations needs to be substantiated from further studies.

\subsection{Conductivity}

The conductivity value of the present study was in the range of 0.075 to $0.12 \mu \mathrm{S} / \mathrm{cm}$, Table 1 . A higher level $5.06-7.017 \mathrm{mS} / \mathrm{cm}$ of conductivity was reported from a natural body of water in Okada town [30]. This result was not supported by those of this present study. However, a lower value $0.006-0.017 \mathrm{mS} / \mathrm{cm}$ was reported [14].

\subsection{Total Phosphorus}

Variations in phosphate content of the pond were shown in Table 1. It was the highest in October with a value of $1.01 \mathrm{mg} / \mathrm{L}$ and lowest in December with a value of $0.83 \mathrm{mg} / \mathrm{L}$, Table 1 . These values were in line with the value of $1.00 \mathrm{mg} / \mathrm{L}$ reported [31, 32]. These values were not comparable with the value of 1.47 $\mathrm{mg} / \mathrm{L}$ reported from polluted water [14]. Phosphate content in dug well ponds ranged from $1.65 \pm 0.06$ to $2.37 \pm 0.17 \mathrm{mg} / \mathrm{L}$, while those from borehole tanks ranged from $1.14 \pm 0.09$ to $2.36 \pm 0.03 \mathrm{mg} / \mathrm{L}$ [16] Phosphate occurs in natural waters at reduced concentrations as many aquatic plants absorb and store phosphorous many times their actual immediate needs [16]. Observance of high concentration may be due to solar radiation, which might have encouraged the biological degradation of organic matter present $[14,16]$.

\section{Conclusions}

The pond of study was not polluted based on results of the chemical parameters observed. Although frequent water quality analysis may not be of economic advantage to the fish farmer, the need to embark on it as often as possible is paramount. This is because such analysis ever remains a quality assurance process to ensure that there are no toxic substances in the ponds leading to possible bio-accumulation. In this way the good health of the aquatic ecosystem, humans and environment can be guaranteed.

\section{Acknowledgments}

The authors wish to acknowledge the assistance rendered by Mr. J.P. Nwokoye for sample collection. The authors are also indebted to Chief P.I Odili (a Chief Laboratory Technologist) for sample analysis. Kind appreciation is extended to Miss Rebecca Madu for typesetting the manuscript.

\section{References}

[1] F.D. Sikoki, F. Veen, Aspects of water quality and the potential for fish production of Shinro Reservour, Nigeria Living System Sustainable Development 2 (2004) 1-7.

[2] C. Bronmark, L.A. Hansson, The Biology of Lakes and Ponds, Oxford University Press, Oxford, 2005, p. 285.

[3] Y. Davenport, Responses of the Blennius pholis to fluctuating salinities, Marine Ecology Progress Series 1 (1993) 101-107.

[4] A. Onomem, I. Davies, A. Ebinimi, Comparative assessment of water qualityparameters of freshwater tidal earthen ponds and stagnant concrete tanks for fish production in Port Harcourt, Nigeria, International Journal of Science and Nature, Society for Science and Nature (SFSN) 1 (1) (2004-2010) 34-37.

[5] N.M. Alykov, Determination of toxic elements in mineral water, All-Russian Conference: Chemical Analysis of Substances and Materials, 2000, pp. 22-34.

[6] J.D. Smith, D.C. Christopher, R.W. Kevin, C.C. Ronald, L.G. Phillip, J.S. Richard, Unified description of temperature-dependent hydrogen bond rearrangements in liquid water, Proc. Natl. Acad. Sci. USA 102 (40) (2005) 14171-14174.

[7] R.M. Spechler, D.M. Schiffer, Springs of Florida, United State Geological Survey Fact Sheet, 2005, pp. 151-195.

[8] W.W. Wood, D.C. Signor, Geochemical factors affecting artificial ground-water recharge in the unsaturated zone: Transactions, American Society of Agricultural Engineers 18 (2000) 677-683.

[9] M.E. Offodile, Water resources management and the Nigerian groundwater system. Water Resource (NAH) 1 (2000) 62-70.

[10] SPC Science, Water analysis handbook 2 (2009) 1-16 


\section{in Asaba Campus, Asaba, Delta State, Nigeria}

[11] AARD: Alberta agriculture and rural development, chemical analysis interpretation of rural household water supplies, Agric-Factsheet. Agdex 716 (2012) 1-4.

[12] O. Akoto, J. Adiyiah, Chemical analysis of drinking water from some communities in the Brong Ahafo region, International Journal of Environmental Science and Technology 4 (2) (2007) 211-214.

[13] Asaba Metrological Station, Metrological Bulletin, Lagos Nigeria, 2005.

[14] J.E. Ehiagbonare, Y.O. Ogunrinde, Physico-chemical analysis of fish pond water in Okada and its environs, Nigeria, African Journal of Biotechnology 9 (36) (2010) 5922-5928.

[15] W.H.O., World Health Organization, International Standard for Drinking-Water, 1958, p. 148.

[16] H.B. Mahananda, M.R. Mahananda, B.P. Mohanty, Studies on the physico-chemical and biological parameters of a fresh water pond ecosystem as an indicator of water pollution, Ecol. Env. and Cons. 11 (3-4) (2005) 537-541.

[17] K.K. Das, A.K. Biswas, A.K. Gangulu, Recycle and re-use of industrial effluent for aquaculture-A case study, Procession of National seminar on Utilisation of Resources, India, 1990, pp. 73-78.

[18] FEPA, Guidelines and standards for environmental pollution control, Fed. Environ. Prot. Agency 27 (1991) 20.

[19] APHA, Standards methods for the examination of waste water 18th edition, American Public Health Association Washington DC, 1992, p. 874.

[20] M.E. Saloom, R.S. Duncan, Low dissolved oxygen levels reduce anti-predator behaviours of the fresh water Clam Corbicula fluminea, Fresh Water Biol. 50 (2005) 1233-1238.

[21] A. Dhawan, S. Karu, Pig dung as pond manure: Effect on water quality pondproductivity and growth of carps in poly culture system, The International Centre for Living
Aquatic Resources Management (ICLARM) Quarterly, Manila 25 (1) (2002) 1-14.

[22] A.E. Ogbeibu, R. Victor, The effects of road and bridge construction on the bank root marcroin vertebrates of a Southern Nigerian stream, Environ. Pollut. 56 (1989) $85-100$.

[23] A.E. Ogbeibu, L.O. Edutie, Effects of brewery effluent on the water quality and rotifers of Ikpoba river, Southern Nigeria, Ecoserve publishers, 2006, pp. 1-17.

[24] N.M. Stone, H.K. Thormforde, Understanding Your Fish Pond Water Analysis Report, University of Arkansas Co-operative Extension Printing Services, 2003, pp. 1-4.

[25] D. Kamal, A.N. Khan, M.A. Raham, M.A. Ahamed, Study on physicochemical properties of water of Mouri River, Khulna, Bangladesh, Pak. J. Biol. Sci. 10 (5) (2007) 710-717.

[26] V.U. Kuz'mina, N.Y. Ushakova, Voprosy Ikhitiologii, J. Biomed. Life Sci. 47 (6) (2007) 837-846.

[27] C.B. Boyd, Water Quality in Warmwater fish ponds, Auburn University Agricultural Experiment Station, Auburn, USA, 1981, p. 359.

[28] W.A. Wurts, R.M. Durbow, Interactions of $\mathrm{pH}$, carbon dioxide, alkalinity and hardness in fish ponds, Southern Regional Aquact, Centre Fact. Sheet No. 464 (1992) 1-4.

[29] L. Swann, A fish farmer's guide to understanding water quality [Online], 2006, http://aquanic.org/publicat/state/il-in/as-503html.

[30] J.E. Ehiagbonare, R.Y. Adjarhore, S.A. Enabulele, Effect of cassava effluents on Okada natural water, Afr. J. Biotechnol. 8 (2) (2009) 2816-2818.

[31] A. David, Studies on fish and fisheries of Godavri and Krishna River systems, Proc. Natl. Acad. Sci. India 1 (33) (1963) 163-286.

[32] D.V. Pahawa, S.N. Mehrotra, Observations on fluctuations in stretch of plankton in relation to certain hydrological condition of River Ganga, Proc. Natl. Acad. Sci. India 36 (1966) 157-189. 